\title{
Antioxidant Activity, Whitening and Anti-wrinkle Effects of Leaf and Seed Extracts of Brassica juncea L Czern.
}

\author{
Jeong-Eun Lee ${ }^{1}$, Ae-Jung Kim ${ }^{2 *}$ \\ ${ }^{1}$ Department of Alternative Medicine, Kyonggi University, Seoul, Korea \\ ${ }^{2}$ Major of Beauty Wellness, The Graduate School of Alternative Medicine, Kyonggi University, Seoul, Korea
}

\author{
*Corresponding author: Ae-Jung Kim, Major \\ of Beauty Wellness, The Graduate School \\ of Alternative Medicine, Kyonggi University, \\ 24, Kyonggidae-ro-9 gil, Seodaemun-gu, \\ Seoul 03752, Korea \\ Tel.: +82 23905012 \\ Fax: +8205042461464 \\ Email: aj5249@naver.com
}

Received June 09, 2020

Revised August 07, 2020

Accepted August 19, 2020

Published September 30, 2020

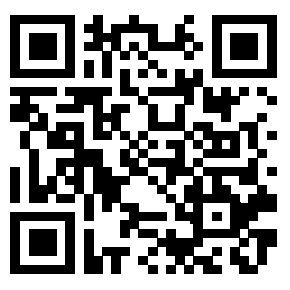

\begin{abstract}
Purpose: This study is to evaluate biological activity of leaf and seed extracts of Brassica juncea $\mathrm{L}$ and examine their utility value as cosmetic ingredients. Methods: Total polyphenol, total flavonoid content, DPPH radical scavenging activity, ABTS radical scavenging activity, and inhibition activities of tyrosinase and elastase were measured to evaluate biological activity of leaf and seed extracts of Brassica juncea L. Czern.(EtOH). In addition, to investigate the antioxidant effect and enzyme inhibition activities in relation to concentrations, correlation of different concentrations of 50 , 100, and $200 \mathrm{mg} / \mathrm{mL}$ of each extract were comparatively analyzed. Results: The highest total polyphenol contents of leaf and seed extracts of Brassica juncea $\mathrm{L}$ (50, 100, and $200 \mathrm{mg} / \mathrm{mL}$ ) were 15.03 and $27.72 \mathrm{mg} \mathrm{TAE} / \mathrm{g}$, respectively, while the total flavonoid contents were 58.84 and $126.75 \mathrm{mg}$ QE/g, respectively. The DPPH scavenging effect was confirmed as $65.26 \%$ in leaf extracts and $83.17 \%$ in seed extracts, while the ABTS radical scavenging effect was confirmed as $47.06 \%$ in leaf extracts and $60.57 \%$ in seed extracts. As a result of evaluation of biological activity analysis on antioxidant effect, the activity in seed was higher than the activity in leaf, and a positive correlation was indicated as highest activities were shown in the concentration of $200 \mathrm{mg} / \mathrm{mL}$ for both leaf and seed. The highest inhibition activities of tyrosinase were $22.33 \%$ and $36.58 \%$, respectively, while the inhibition activities of elastase were $33.45 \%$ and $40.21 \%$, respectively. In leaf extracts, the inhibition activities of tyrosinase and elastase increased as the concentration increased, while in seed extract, the inhibition activities of elastase increased as the concentration increased, but the inhibition activities decreased when the concentration of the extract reached above a certain level. Conclusion: The results of the study confirmed leaf and seed extracts of Brassica juncea L. Czern. have excellent antioxidant effect and inhibition effect on activities of tyrosinase and elastase, and their utility value as cosmetic ingredients would be high.
\end{abstract}

Keywords: Brassica juncea L, Antioxidant activity, Tyrosinase inhibitory activity, Elastase inhibitory activity, Bioactivity

\section{Introduction}

갓(Brassica juncea L.)은 십자화과 또는 배추과에 속하는 경엽 채소류 중의 하나로 겨자의 잎(mustard leaf)을 말하며, 우리나라 각지에서 재배되고 있다. 주로 잎 또는 지상부 전체는 채소로, 종자 는 주요 향신료로 사용되고 있으며, 국내뿐 만 아니라 세계 전 지역 에서 재배되고 있다(Shin, 2000). 국내에서는 만생평경대엽종이 전
남 여수 돌산 세구치 마을에 처음 도입되어 재배되기 시작하였는데, 해양성 기후와 토양 환경의 영향으로 고품질의 갓을 생산하고 있다 (Choi et al., 2001). 돌산 갓은 다른 지역의 갓에 비해 매운맛이 적 고 특유의 향이 존재하고 방충망사 재배방식으로 농약을 사용하지 않는 등 특징이 우수하여 여수시의 특산품으로 지정되어 있으며, 용 도에 따라 유(油), 채소, 향신료 등 그 용도가 다양하게 이용되고 있 다(Choi et al., 2001; Lee et al., 2010) 
종자는 4종이 있으나 갈색과 흑색이 유사하여 백겨자(white mustard), 황겨자(yellow mustard) 및 흑겨자(brown black mustard) 3 종으로 구분한다. 백겨자와 황겨자는 myrosinase에 의해 배당체 sinalbin이 가수분해되어 p-hydroxybenzyl isothiocyanate, glucose 및 sinapine bisulfate를 생성하고, 흑겨자는 배당체인 sinigrin이 myrosinase에 의해 가수분해되어 자극적인 방향성과 톡 쏘는 맛을 가진 allyl isothiocyanate와 glucose 및 potassium hydrogen sulfate를 생성하는데, 이 isothiocyanate 성분은 강한 항 균성이 있는 것으로 알려져 있다(Seo et al., 1996).

갓의 조직이 상처를 받거나 종자를 분쇄하면 생체 속에 함유된 sinigrin (glucosinolate)이 조직에 존재하는 효소 myrosinase에 의 해 가수분해되어 glucose와 함황 성분 및 관련물질 등을 생성하게 되 는데, 그 중 약 $1 \%$ 의 휘발성인 allyl isothiocyanate (AIT)가 유리되 면서 특유의 향과 매운맛을 내는 주성분으로 알려져 있으며(Kang, 1995; Kim et al., 2012), 유리된 성분들은 효모, 곰팡이, 각종 박테 리아 등에 대한 항균력이 있어 김치 제조 시 발효를 지연시켜 저장 성을 높여준다. Glucosinolate류 성분과 함께 Brassica juncea 속 식 물의 폴리페놀 성분들은 치유적인 생체 활성 성분으로 알려져 있으 며, Brassica 속 식물에는 약 200종류의 glucosinolate 성분이 확인 되었는데, 이는 종자에도 존재하는 것으로 밝혀졌다(Kumar et al., 2011).

또한 칼슘, 철, 인, 칼륨, 비타민 $\mathrm{A}, \mathrm{B}, \mathrm{C}$, 조단백질 등의 함량이 높 아 무기질 공급원이 되고 특히 비타민 $\mathrm{A}$ 의 전구물질은 $\beta$-carotene, chlorophyll, ascorbic acid의 함량이 타 경엽 채소류에 비해 많이 함 유되어 있으며, 이러한 성분들은 항산화 활성을 가지고 있다고 보고 되고 있다. 또한 여러 가지 황 화합물을 함유하고 있어 항균, 항곰팡 이 등의 효능이 있는 것으로 알려져 있다(Choi et al., 2001; Jang et al., 2016).

Brassica 속 식물은 대부분 glucosinolate가 함유되어 있으며 재 배 품종 및 산지에 따라 조성에 있어 현저한 차이를 나타낸다. 그 중 에서도 B. juncea에는 glucosinolate의 함량이 가장 높아 종자 뿐만 아니라 경엽부도 독특한 신미와 향이 강하다. Glucosinolate 성분은 수용성 성분으로 myrosinase 효소와 물이 있으면 isothiocyanate, thiocyanate, nitrile 성분이 생성된다( Kumar et al., 2001; Shin, 2000).

그 중 allyl isothiocyanate, 2-phenyl ethyl isothiocyanate, 5-methyl thiopentyl isothiocyanate, benzyl isothiocyanate 등의 성분이 있어 항균작용을 나타낸다(Shin, 2000). 돌산 갓 (Brassica juncea)의 주요 휘발성 물질은 allyl isothiocyanate, 3-butenyl isothiocyanate, $\mathrm{n}$-hexyl isothiocyanate, $\mathrm{b}$-phenylethyl isothiocyanate 및 sec-butyl isothiocyanate 순으로 함량이 많았으 며, nitril류도 일부 확인되었다. 돌산 갓에 함유된 휘발성 물질은 총 26종류, 주요물질은 isothiocyanate류인 것으로 보아 이는 돌산 갓의 독특한 맛과 향을 부여하는 요소 중 하나인 것으로 생각된다(Cho et al., 1993b).

Brassica juncea는 비타민 $\mathrm{C}$ 와 $\beta$-carotene 함량이 타 중국 채소 류와 비교하였을 때에도 특히 높고 잎에서 분리된 thioglucosides는 생리활성 화합물인 것으로 보고된 바 있어 식이 항산화제로 이용하 기 위한 많은 연구가 주목받고 있으며, 항균제, 이뇨제 및 거담제의 용도로 이용되어졌다(Yahaghi et al., 2018).

Brassica juncea는 생리활성 물질로서 체내에서 약리작용을 나타 내는 식물성 2차 대사산물인 glucosinolate, flavonoid, polyphenol류, 함황 화합물 등이 풍부하여 면역계를 강화 시켜 건강유지에 기여하고 암을 예방하는 대표적인 식품으로 여겨지고 있다(Oh et al., 2015).

이와 같이 갓은 다량의 함황 물질, 항산화 물질 등을 함유하고 있 어 이에 대한 기능성을 규명하고 우수성에 관한 연구가 활성화 되면 서 갓 제품의 다양화, 고부가가치의 기능성부여로 여수지역 관광 상 품으로 자리 매김하고 있다. 농촌진흥청에 의하면, 2001년부터 우리 품종 육성을 위한 유전자원 수집 등 연구개발 사업을 추진하여 2009 년, 우리 품종이 3 동이(늦동이, 순동이, 신동이)와 3 돌이(짱돌이, 쌈 돌이, 꽃돌이), 이외에 자람이, 자랑이, 알싸미, 매코미 등 10 개 품종 이 육성 국립종자원에 품종보호출원 중에 있다.

천연물 소재 중 항산화, 항염증 그리고 미생물에 대한 항균작용이 있는 것으로 알려진 갓(mustard leaf)에 대한 연구로는 갓과 겨자의 항산화 활성성분에 관한 연구(Han et al., 1987), 돌산 갓 즙액의 항 암성과 항산화 및 $\mathrm{ACE}$ 저해 활성에 관한 연구(Choi et al., 2001), 돌 산 갓의 생리기능성 탐색 및 응용식품 개발(Lim, 2002) 등이 있으 며, 그에 따라 천연 기능성 소재로 인정받고 있다. 또한 갓 정유의 항 진균 작용(Shin \& Kang, 2001), 갓 추출물의 항균활성(Kang et al., 1994b), 돌산 갓 전 처리 추출물의 항균활성 및 열안정성(Park et al., 1995), 돌산 갓의 유기산, 무기질, 지방산 및 섬유소 조성(Park et al., 1993)과 carotenoids 및 chlorophyll 함량(Cho et al., 1993a), 갓(Brassica juncea)의 에탄올 추출물이 미생물 생육에 미치는 영향 (Kang et al., 1994a) 등 많은 연구를 통해 입증되었으나, 현재까지 화장품 소재로써 갓의 잎과 종자에 대한 생리활성 연구는 부족한 실 정이다.

따라서 본 연구는 갓(Brassica juncea L. Czern.)의 잎, 종자 추출 물의 생리활성 평가와 항산화, 미백, 항주름 활성을 평가하여 화장품 소재로써 이용가치를 규명하고자 하였다.

\section{Methods}

\section{1. 실험재료}

본 연구에 사용된 갓(mustard leaf, Brassica juncea L. Czern.)은 전라남도 여수시 돌산읍 소재의 밭에서 2018년 9월 28일 파종하여 2019년 1월 25일에 재배한 갓(늦동이 종자: Neujdongi)을 사용하였 다. 


\section{2. 추출물 제조}

갓의 잎, 종자는 시료 $50 \mathrm{~g}$ 에 무게 대비 각각 20배 부피의 $70 \%$ $\mathrm{EtOH} 1 \mathrm{~L}$ 를 넣어 $72 \mathrm{~h}$ 동안 상온에서 추출하였고, 추출액 만을 분 리하기 위해 vacuum pump (흡인여과기, $\mathrm{HC}-30$; Hanil Science Industrial Co. Ltd., Korea)에 3회 여과(No. 2, Whatman, Maidstone, England)시켜 에탄올 추출액을 얻었다. 얻어진 추 출액은 vacuum rotary evaporator (진공감압농축기, $\mathrm{N}-1110$; EYELA, Tokyo, Japan)로 추출 용매인 에탄올을 제거하여 농축하 였으며, 농축 후 원심분리기(Combi 514R; Hanil Science Medical Co. Ltd., Korea)에서 $3500 \mathrm{rpm}, 15 \mathrm{~min}$ 간 원심 분리하여 얻어진 상등액을 최종농도 $50,100,200 \mathrm{mg} / \mathrm{mL}$ 을 시료로 사용하였다.

\section{Total polyphenol content}

총 폴리페놀 함량은 $\mathrm{F}-\mathrm{C}$ 시약을 사용하는 Singleton \& Rossi 의 방법(Singleton \& Rossi, 1965)을 변형하여 측정하였다. 시료 $350 \mu \mathrm{L}$ 에 50\% Folin-Ciocalteu 시약(Sigma-Aldrich) $70 \mu \mathrm{L}$ 를 가 하여 3 분간 정치한 후, $2 \%(\mathrm{w} / \mathrm{v}) \mathrm{Na}_{2} \mathrm{CO}_{3}$ 용액 $\left(\mathrm{Na}_{2} \mathrm{CO}_{3}\right.$; SigmaAldrich) $350 \mu \mathrm{L}$ 를 첨가하여 $1 \mathrm{~h}$ 반응시킨 후, ELISA microplate reader(Infinite M200 pro Nanoquant; Tecan Austria GmbH, Grödig, Austria)를 이용하여 $750 \mathrm{~nm}$ 에서 흡광도를 측정하였다. 총 폴리페놀 함량은 tannic acid (Sigma-Aldrich)를 이용하여 작성 한 표준곡선으로부터 구하였다.

\section{Total flavonoid content}

총 플라보노이드 함량은 Davis의 방법(Davis, 1947)을 변형하여 측정하였다. 시료 $70 \mu \mathrm{L}$ 에 diethylene glycol $700 \mu \mathrm{L}$ 를 첨가하고 다 시 $1 \mathrm{~N}-\mathrm{NaOH}$ 용액 $7 \mu \mathrm{L}$ 를 첨가한 후 $37^{\circ} \mathrm{C}$ 에서 $1 \mathrm{~h}$ 반응시킨 후 ELISA microplate reader (Infinite M200 pro Nanoquant; Tecan Austria GmbH, Grödig, Austria)를 이용하여 $420 \mathrm{~nm}$ 에서 흡광도 를 측정하였다. 총 플라보노이드 함량은 quercetin을 이용하여 작성 한 표준곡선으로부터 구하였다.

\section{DPPH radical scavenging activity}

1,1-diphenyl-2-picrylhy drazyl (DPPH; Sigma-Aldrich, USA) radical 소거능은 Blois의 방법(Blois, 1958)을 변형하여 다 음과 같이 실시하였다. 시료 $100 \mu \mathrm{L}$ 에 $1.5 \times 10^{-4} \mathrm{M} \mathrm{DPPH}$ 용액 (Sigma-Aldrich) $100 \mu \mathrm{L}$ 를 가하여 실온의 암실에서 $30 \mathrm{~min}$ 간 정 치한 후 ELISA microplate reader (Infinite M200 pro Nanoquant; Tecan Austria GmbH, Austria)를 이용하여 $517 \mathrm{~nm}$ 에서 흡광도를 측정하였으며, 소거능은 다음의 식을 이용하여 산출하였다.

$\mathrm{DPPH}$ radical scavenging activity $(\%)=[(\mathrm{Ac}-\mathrm{As}) / \mathrm{Ac}] \times 100$

Ac: $\mathrm{DPPH}$ 용액만 첨가한 반응용액의 흡광도

$\mathrm{As}: \mathrm{DPPH}$ 용액과 시료를 모두 첨가한 반응용액의 흡광도

\section{ABTS radical scavenging activity}

ABTS (2,2'-azino-bis-3-ethylbenzo-thiazoline-6-sulfonic acid; Sigma-Aldrich, USA) radical 소거능은 Pellegrin의 방 법(Pellegrin et al., 1999)으로 측정하였다. ABTS $7.4 \mathrm{mM}$ 과 potassium persulfate $2.6 \mathrm{mM}$ 을 같은 비율로 섞어 하루 동안 암 소에 방치하여 $\mathrm{ABTS}$ 양이온을 형성시킨 후 $732 \mathrm{~nm}$ 에서 흡광도 값이 $0.70 \pm 0.03$ 이 되도록 $1 \times \mathrm{PBS}$ 로 희석하였고, 희석된 $\mathrm{ABTS}$ 용액 $190 \mu \mathrm{L}$ 에 시료 $10 \mu \mathrm{L}$ 를 가하여 $60 \mathrm{~min}$ 정치한 후 ELISA microplate reader (Infinite M200 pro Nanoquant)를 이용하여 $732 \mathrm{~nm}$ 에서 흡광도를 측정하였으며, 소거능은 다음의 식을 이용하 여 산출하였다.

ABTS radical scavenging activity $(\%)=[(A c-A s) / A c] \times 100$

$\mathrm{Ac}$ : DPPH용액만 첨가한 반응용액의 흡광도

As: DPPH용액과 시료를 모두 첨가한 반응용액의 흡광도

\section{Tyrosinase inhibitory activity}

Tyrosinase 저해활성은 Tomita의 방법(Tomita et al., 1990) 을 변형하여 측정하였다. L-tyrosine 으로부터 멜라닌 생성 과 정에서 tyrosinase 효소작용에 의해 생성되는 DOPA 생성물을 측정하는 방법으로 $100 \mathrm{mM}$ 인산완충용액 $(\mathrm{pH}$ 6.8) $115 \mu \mathrm{L}$ 에 mushroom tyrosinase $(300 \mathrm{U} / \mathrm{mL}) 20 \mu \mathrm{L}$ 을 첨가하여 $37^{\circ} \mathrm{C}$ 에 서 $15 \mathrm{~min}$ preheating 시킨 후, $10 \mathrm{mM} \mathrm{L}-\mathrm{DOPA}$ 를 녹인 기질액 $15 \mu \mathrm{L}$ 및 시료 $40 \mu \mathrm{L}$ 을 첨가하여 $37^{\circ} \mathrm{C}$ 에서 $25 \mathrm{~min}$ 반응시켜 생성 된 DOPA chrome을 ELISA microplate reader(Infinite M200 pro Nanoquant)를 이용하여 $475 \mathrm{~nm}$ 에서 흡광도를 측정하였으며, 저해 활성은 다음의 식을 이용하여 산출하였다.

Tyrosinase inhibitory activity $(\%)=[1-\{(\mathrm{As}-\mathrm{AsB}) /(\mathrm{Ac}-\mathrm{AcB})\}] \times$ 100

As: 효소와 시료를 모두 첨가한 반응용액의 흡광도

$\mathrm{AsB}:$ 시료만 첨가한 반응용액의 흡광도

$A c$ : 효소만 첨가한 반응용액의 흡광도

$\mathrm{AcB}$ : 효소와 시료를 모두 첨가하지 않은 용액의 흡광도

\section{Elastase inhibitory activity}

Elastase 저해활성은 Kraunsoe의 방법(Kraunsoe et al., 1996) 을 변형하여 측정하였다. $200 \mathrm{mM} \mathrm{Tris}-\mathrm{HCl}$ buffer (pH 8.0) $25 \mu \mathrm{L}$ 에 Procine pancreatic elastase (PPE) $30 \mu \mathrm{L}$ 를 첨가하여 15 min간 preheating 시킨 후, N-Succinyl-Ala-Ala_Ala-pnitroanilide $5 \mathrm{mg}$ 에 Tris- $\mathrm{HCl}$ buffer $1 \mathrm{~mL}$ 를 넣어 용해한 기질 액 $25 \mu \mathrm{L}$ 및 시료 $40 \mu \mathrm{L}$ 를 첨가하여 $25^{\circ} \mathrm{C}$ 에서 $25 \mathrm{~min}$ 반응시켜 ELISA microplate reader (Infinite M200 pro Nanoquant)를 이용 하여 $410 \mathrm{~nm}$ 에서 흡광도를 측정하였으며, 저해활성은 다음의 식을 이용하여 산출하였다.

Elastase inhibitory activity $(\%)=[1-\{(\mathrm{As}-\mathrm{AsB}) /(\mathrm{Ac}-\mathrm{AcB})\}] \times 100$ 
As: 효소와 시료를 모두 첨가한 반응용액의 흡광도

$\mathrm{AsB}:$ 시료만 첨가한 반응용액의 흡광도

$\mathrm{Ac}$ : 효소만 첨가한 반응용액의 흡광도

$\mathrm{AcB}:$ 효소와 시료를 모두 첨가하지 않은 용액의 흡광도

\section{9. 통계처리}

실험 결과의 분석은 SPSS statistics 24 (SPSS Institute, USA)를 이용하여 평균과 표준편차를 구하고 통계 분석을 실시하였다. 두 변 수 간의 차이를 분석할 경우에는 student's $t$-test를 실시하였고, 독 립변수 요인이 3 개 이상인 경우에는 one-way ANOVA를 실시한 후, Duncan's multiple range test로 각 시료의 평균 차이에 대한 사후 검정을 유의수준 $5 \%(p<0.05)$ 에서 실시하였다.

\section{Results and Discussion}

\section{1. 갓의 잎, 종자 추출물의 항산화 성분}

1) Total polyphenol content

페놀 화합물은 식물계에 널리 분포되어 있는 2 차 대사산물로 다 양한 구조와 분자량을 가진다. 또한 phenolic hydroxy기를 가지 고 있어 단백질과 같은 큰 분자들과 결합하는 성질이 있으며, 항산 화 효능의 생리활성 기능을 가지고 있다. $-\mathrm{OH}$ 기를 통해 수소 공여 와 페놀 고리 구조의 안정화에 의해 항산화 활성을 가지며 항암 및 항균 효과 등의 생리활성을 가지는 것으로 알려져 있다(Cha et al, 1999; Shin et al., 2014).

본 연구에서는 tannic acid를 표준물질로 한 갓의 잎, 종자 추출물 $(50,100,200 \mathrm{mg} / \mathrm{mL})$ 의 총 폴리페놀 함량을 측정하였으며 그 결 과, 4.32-27.72 mg TAE/g 범위의 값을 보였다(Figure 1). Leaf와 seed 모두 $200 \mathrm{mg} / \mathrm{mL}$ 농도에서 총 폴리페놀 함량이 가장 높았으 며, $50 \mathrm{mg} / \mathrm{mL}$ 일 때는 leaf $4.32 \pm 0.04 \mathrm{mg} \mathrm{TAE} / \mathrm{g}$, seed 9.58土 $0.18 \mathrm{mg}$ TAE$/ \mathrm{g}, 100 \mathrm{mg} / \mathrm{mL}$ 일 때는 leaf $7.89 \pm 0.02 \mathrm{mg} \mathrm{TAE} / \mathrm{g}$, seed $14.96 \pm 0.43 \mathrm{mg} \mathrm{TAE} / \mathrm{g}, 200 \mathrm{mg} / \mathrm{mL}$ 일 때는 leaf $15.03 \pm$ $0.13 \mathrm{mg} \mathrm{TAE} / \mathrm{g}$, seed $27.72 \pm 0.25 \mathrm{mg} \mathrm{TAE} / \mathrm{g}$ 으로 농도가 높아질 수록 총 폴리페놀 함량이 높았다.

결과적으로 각각의 추출물 모두 농도가 높을수록 페놀 함량이 높 아졌고 대체로 seed가 leaf 보다 페놀 함량이 높은 것을 알 수 있었 다(Figure 1).

Oh et al., (2016)의 연구에서 돌산 갓의 잎과 종자를 acetonitrile 용매 추출하여 총 폴리페놀 함량을 측정한 결과, 잎은 $368.67 \mathrm{mg}$ $\mathrm{GAE} / 100 \mathrm{~g}$, 종자는 $404.33 \mathrm{mg} \mathrm{GAE} / 100 \mathrm{~g}$ 으로 잎보다 종자에 서 총 폴리페놀 함량이 더 높은 것으로 나타나 본 연구와 유사한 결 과임을 알 수 있었다. 또한 Lee (2017)의 연구에서 동결건조 한 갓 (Brassica juncea L.)의 총 폴리페놀 함량은 $234.86 \mathrm{mg} / \mathrm{g}$, 열풍건 조 한 갓의 총 폴리페놀 함량은 $212.21 \mathrm{mg} / \mathrm{g}$ 으로 보고하여 갓의 총

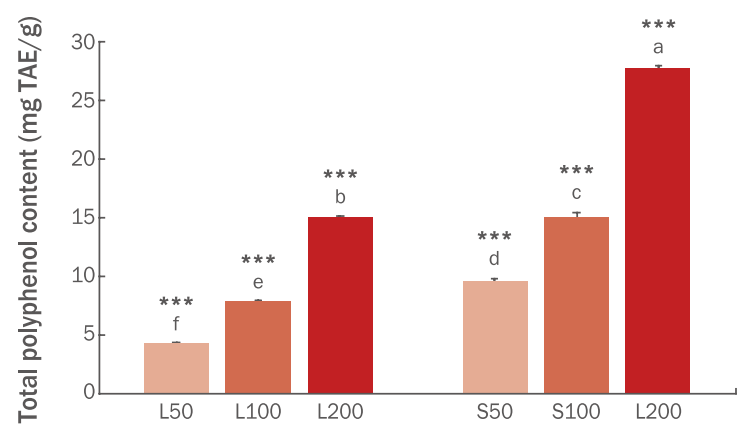

Figure 1. Total polyphenol content of mustard (Brassica juncea $\mathrm{L}$. Czern.) leaf and seed.

The leaf and seed extracts of Brassica juncea L. were assessed in concentration of $50,100,200 \mathrm{mg} / \mathrm{mL}$. The result is shown as an average (means $\pm S D, n=3$ ). The significance level was determined to be $p<0.05$ via Duncan's multiple range test. ${ }^{* * *} p<0.001$ shows the significance difference between L50 and S50, L100 and S100, and L200 and S200 via student's t-test.

폴리페놀 함량이 매우 높은 것을 알 수 있었다.

본 연구에서도 갓(Brassica juncea L. Czern.)의 잎, 종자 추출물 $(\mathrm{EtOH})$ 의 총 폴리페놀 함량이 높은 것으로 나타났으며, Kim et al. (2014)에 의하면 페놀 화합물은 품종이나 재배방식 및 환경과 같은 조건에 의해 다양한 결과를 나타낼 수 있다고 한 바, 폴리페놀 함량 은 추출 농도와 용매 및 추출 방식에 기인하여 상대적인 차이가 있 는 것으로 보인다.

2) Total flavonoid content

플라보노이드는 노란색이나 담황색을 나타내는 페놀계 화합물의 총칭으로 자연계에 널리 분포하고 있고 폴리페놀과 같이 채소류, 식 물의 잎, 꽃, 과실, 줄기 및 뿌리 등에 함유되어 있으며, 항염증 및 항 알레르기 효과를 비롯한 광범위한 생화학, 약리학적 효능이 있는 것으로 알려져 있다(Hertog et al., 1993; Kim et al., 2014). 또한 플라보노이드는 혈관 내에서 nitric oxide와 superoxide의 반응으로 생성되는 peroxynitrite와 전구체인 superoxide를 직접적으로 제거 해주는 것으로 알려져 있다(Heim et al., 2002).

본 연구에서는 quercetin을 표준물질로 한 갓의 잎, 종자 추출 물 $(50,100,200 \mathrm{mg} / \mathrm{mL})$ 의 총 플라보노이드 함량을 측정하였으 며 그 결과, $11.89-126.75 \mathrm{mg} \mathrm{QE} / \mathrm{g}$ 범위의 값을 보였다(Figure 2). Leaf와 seed 모두 $200 \mathrm{mg} / \mathrm{mL}$ 농도에서 총 플라보노이드 함량 이 가장 높았으며, $50 \mathrm{mg} / \mathrm{mL}$ 일 때는 leaf $11.89 \pm 0.96 \mathrm{mg} \mathrm{QE} /$ $\mathrm{g}$, seed $27.01 \pm 0.82 \mathrm{mg} \mathrm{QE} / \mathrm{g}, 100 \mathrm{mg} / \mathrm{mL}$ 일 때는 leaf $27.54 \pm$ $0.38 \mathrm{mg} \mathrm{QE} / \mathrm{g}$, seed $60.26 \pm 2.15 \mathrm{mg} \mathrm{QE} / \mathrm{g}, 200 \mathrm{mg} / \mathrm{mL}$ 일 때 는 leaf $58.84 \pm 1.11 \mathrm{mg} \mathrm{QE} / \mathrm{g}$, seed $126.75 \pm 1.59 \mathrm{mg} \mathrm{QE} / \mathrm{g}$ 으로 농도가 높아질수록 총 플라보노이드 함량이 높았다. 


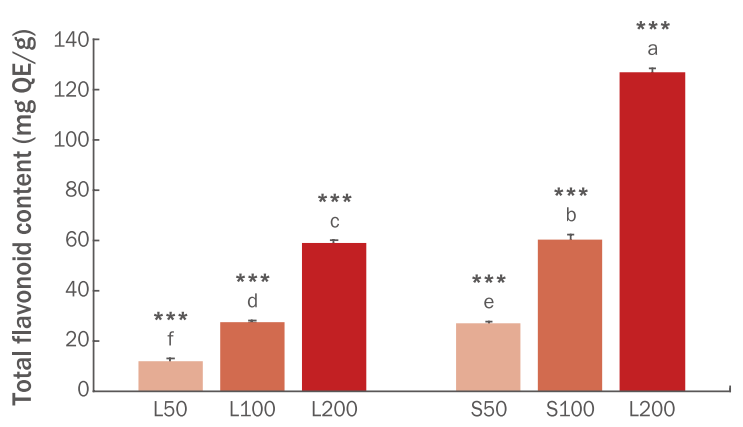

Figure 2. Total flavonoid content of mustard (Brassica juncea L. Czern.) leaf and seed.

The leaf and seed extracts of Brassica juncea L. were assessed in concentration of $50,100,200 \mathrm{mg} / \mathrm{mL}$. The result is shown as an average (means $\pm S D, n=3$ ). The significance level was determined to be $p<0.05$ via Duncan's multiple range test. ${ }^{* * *} p<0.001$ shows the significance difference between L50 and S50, L100 and S100, and L200 and S200 via student's $t$-test.

결과적으로 각각의 추출물 모두 농도가 높을수록 플라보노이드 함량이 높아졌고 대체로 seed가 leaf 보다 플라보노이드 함량이 높 은 것을 알 수 있었다(Figure 2).

Brassica 속 식물의 페놀 화합물은 flavonol과 hydroxycinnamic acid이며, 주요 flavonol 성분은 quercetin, kaempferol, isorhamnetin이 있다(Kumar et al., 2011). Lee (2017)의 연구에 서 열풍건조 한 갓의 총 플라보노이드 함량은 $125.04 \mathrm{mg} \mathrm{RE} / \mathrm{g}$, 동 결건조 한 갓의 총 플라보노이드 함량은 $84.91 \mathrm{mg} \mathrm{RE} / \mathrm{g}$ 으로 보고 하였으며, 본 연구에서도 갓(Brassica juncea L. Czern.)의 잎, 종 자 추출물 $(\mathrm{EtOH})$ 의 총 플라보노이드 함량이 높은 것으로 나타났다. Kim et al. (2014)에 의하면 페놀 화합물은 환경조건에 의해 다양한 결과를 나타내고 수확 시기는 식물 화학 물질의 함량과 생물학적 효 과에 영향을 줄 수 있다고 한 바, 플라보노이드 함량은 재배시기, 추 출 농도와 용매 및 추출 방식에 기인하여 상대적인 차이가 있는 것 으로 보인다.

\section{2. 갓의 잎, 종자 추출물의 항산화 활성}

1) DPPH radical scavenging activity

$\mathrm{DPPH}$ radical 소거능 방법은 $\mathrm{DPPH}$ 의 환원정도를 기준으로 측 정물질의 환원정도와 항산화 정도를 가늠할 수 있다. $\mathrm{DPPH}$ 는 비 교적 안정한 free radical로 쉽게 수소원자를 받아들이는 성질이 있 으며, 함황 아미노산인 cysteine, glutathion, 방향족아민(aromatic amine), ascorbic acid 등에 의해 환원되어 보라색의 DPPH가 자체 정색성을 잃어 무색의 diphenyl-picrylhydrazine으로 탈색되어 흡 광도가 변하게 되는데, 다양한 천연물질의 자유 라디칼 소거능 측정 에 널리 사용되고 있다 (Jung et al., 2019; Park \& Ryu, 2019).

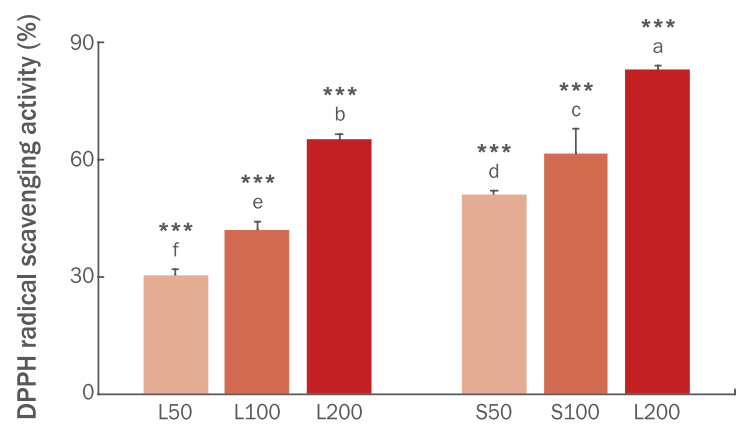

Figure 3. DPPH radical scavenging activity of mustard (Brassica juncea L Czern.) leaf and seed.

The leaf and seed extracts of Brassica juncea $L$ were assessed in concentration of $50,100,200 \mathrm{mg} / \mathrm{mL}$. The result is shown as an average (means $\pm S D, n=3$ ). The significance level was determined to be $p<0.05$ via Duncan's multiple range test. ${ }^{* * *} p<0.001$ shows the significance difference between L50 and S50, L100 and S100, and L200 and S200 via student's $t$-test.

본 연구에서는 갓의 잎, 종자 추출물 $(50,100,200 \mathrm{mg} / \mathrm{mL})$ 의 항 산화 활성을 알아보기 위해 DPPH radical 소거능을 측정하여 그 결 과를 Figure 3에 제시하였다. 그 결과 30.53-83.17\% 범위의 값을 보였다(Figure 3). Leaf와 seed 모두 $200 \mathrm{mg} / \mathrm{mL}$ 농도에서 DPPH radical 소거능이 가장 높았으며, $50 \mathrm{mg} / \mathrm{mL}$ 일 때는 leaf $30.53 \pm$ $1.45 \%$, seed $50.96 \pm 1.13 \%, 100 \mathrm{mg} / \mathrm{mL}$ 일 때는 leaf $42.11 \pm$ $2.03 \%$, seed $61.70 \pm 6.28 \%$ 였다, $200 \mathrm{mg} / \mathrm{mL}$ 일 때는 leaf 65.26 $\pm 1.18 \%$, seed $83.17 \pm 0.88 \%$ 로 가장 높았다.

결과적으로 각각의 추출물 모두 농도가 높을수록 $\mathrm{DPPH}$ radical 소거능이 높아졌고 대체로 seed가 leaf 보다 소거능이 높은 것을 알 수 있었다(Figure 3).

Oh et al. (2016)의 연구에서 돌산 갓의 잎과 종자를 acetonitrile 용매 추출하여 DPPH radical 소거능을 측정한 결과, 잎과 종자 모두 $16.67 \%$ 로 낮은 소거능이 나타났다. 반면, 본 연구에서는 소거능이 높은 것으로 나타나 Oh et al. (2016)의 연구와 상이한 결과를 보였 다. 또한 Choi et al. (2001)의 연구에서는 60 일 자란 돌산 갓의 잎, 뿌리 즙액의 DPPH radical 소거능은 각각 $65.6 \%, 11.8 \%$ 로 보고된 바 있다.

본 연구에서도 갓(Brassica juncea L. Czern.)의 잎, 종자 추출물 $(\mathrm{EtOH})$ 의 DPPH radical 소거능이 우수하였으며, 소거능 값은 부위 별로 차이를 보였다. 본 연구에서 leaf와 seed의 DPPH radical 소거 능 차이는 재배시기와 추출 용매 및 추출 방식에 기인하여 상대적인 차이가 있는 것으로 보인다.

\section{2) ABTS radical scavenging activity}

ABTS와 potassium persulfate이 암소에 있을 때 활성 양이온인 


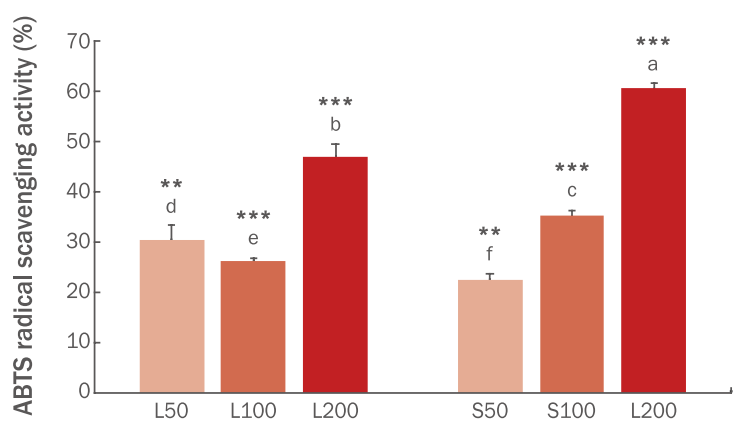

Figure 4. ABTS radical scavenging activity of mustard (Brassica juncea L. Czern.) leaf and seed.

The leaf and seed extracts of Brassica juncea $L$ were assessed in concentration of $50,100,200 \mathrm{mg} / \mathrm{mL}$. The result is shown as an average (means $\pm \mathrm{SD}, \mathrm{n}=3$ ). The significance level was determined to be $p<0.05$ via Duncan's multiple range test. ${ }^{* * *} p<0.001$ shows the significance difference between L100 and S100, L200 and S200 via student's $t$-test. ${ }^{* *} p<0.01$ shows the significance difference between L50 and S50 via student's $t$-test.

$\mathrm{ABTS}+$ 가 생성되고, 시료의 항산화 활성에 의해 $\mathrm{ABTS}+$ 가 소거되 어 청록색을 띠게 된다. ABTS+탈색 반응은 생성된 자유 라디칼 소 거 정도를 나타내는 것으로 항산화력을 측정할 수 있으며, 소수성 및 친수성 조건의 시료에서도 적용이 가능하다(Lee, 2017; Oh et al., 2016).

본 연구에서는 갓의 잎, 종자 추출물 $(50,100,200 \mathrm{mg} / \mathrm{mL})$ 의 항 산화 활성을 알아보기 위해 ABTS radical 소거능을 측정하여 그 결 과를 Figure 4에 제시하였다. 그 결과 22.50-60.57\% 범위의 값을 보였다(Figure 4). Leaf와 seed 모두 $200 \mathrm{mg} / \mathrm{mL}$ 농도에서 ABTS radical 소거능이 가장 높았으며, $50 \mathrm{mg} / \mathrm{mL}$ 일 때는 leaf $30.53 \pm$ $2.97 \%$, seed $22.50 \pm 1.27 \%, 100 \mathrm{mg} / \mathrm{mL}$ 일 때는 leaf $26.32 \pm$ $0.49 \%$, seed $35.19 \pm 0.98 \%, 200 \mathrm{mg} / \mathrm{mL}$ 일 때는 leaf $47.06 \pm$ $2.48 \%$, seed $60.57 \pm 1.13 \%$ 로 가장 높았다.

결과적으로 각각의 추출물 모두 농도가 높을수록 ABTS radical 소거능이 높아졌고 대체로 seed가 leaf 보다 소거능이 높은 것을 알 수 있었다(Figure 4).

Oh et al. (2016)의 연구에서는 돌산 갓의 잎과 종자를 acetonitrile 용매 추출하여 ABTS radical 소거능을 측정하였는데, 잎은 $50.07 \%$, 종자는 $48.67 \%$ 로 잎이 종자보다 소거능이 높은 것으 로 나타났다. 반면, 본 연구에서는 종자 추출물이 잎 추출물보다 소 거능이 높은 것으로 나타나 Oh et al. (2016)의 ABTS radical 소거 능 측정 결과와 상이한 결과를 보였다. 또한, Lee (2017)의 연구에 서 동결 건조한 갓과 열풍 건조한 갓의 $50 \% \mathrm{ABTS}$ radical 소거능 $\left(\mathrm{IC}_{50}\right)$ 은 각각 $0.89 \mathrm{mg} / \mathrm{mL}, 0.65 \mathrm{mg} / \mathrm{mL}$ 으로 나타나 갓의 $\mathrm{ABTS}$ radical 소거능이 우수한 것을 알 수 있었다.

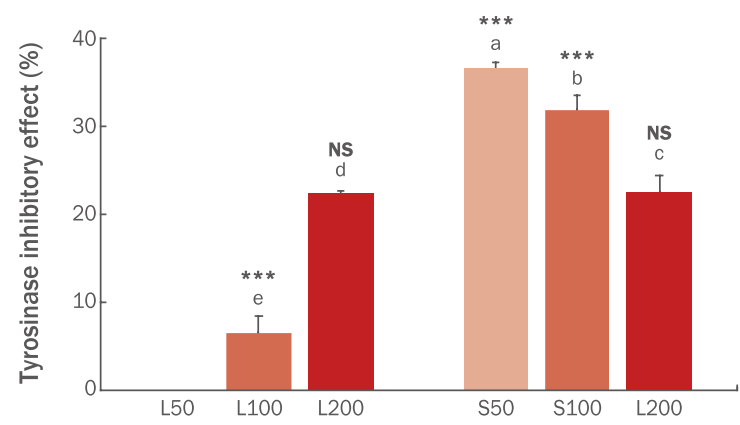

Figure 5. Tyrosinase inhibitory effect of mustard (Brassica juncea L. Czern.) leaf and seed.

The leaf and seed extracts of Brassica juncea $\mathrm{L}$ were assessed in concentration of $50,100,200 \mathrm{mg} / \mathrm{mL}$. The result is shown as an average (means $\pm S D, n=3$ ). The significance level was determined to be $p<0.05$ via Duncan's multiple range test. ${ }^{* * *} p<0.001$ shows the significance difference between L100 and S100, L200 and S200 via student's $t$-test. NS, not significant.

Kaur \& Kapoor (2002)에 의하면 여러 연구에서 식물 화학 성 분은 강력한 항산화 효능과 함께 암, 심혈관 질환을 비롯한 주요 질병으로부터 보호하는 역할을 하고 ascorbic acid, tocopherol, $\beta$-carotene과 같은 비타민을 포함하는 항산화 물질로부터 기여되 는 것으로 알려져 있으며, 에탄올 추출은 물 추출 보다 식물에 존재 하는 카로티노이드와 같은 항산화 물질들을 추출하기에 더 효과적 이라고 하였다.

Brassica juncea의 종자는 단백질 함량이 높아 우수한 영양가를 지니며, 향과 맛에 영향을 주는 sinigrin과 같은 glucosinolate가 다 량 함유되어 있다. 이러한 glucosinolate는 myrosinase 효소에 의해 isothiocyanate로 분해되어 향과 맛을 결정하게 되는데, 이는 항산 화, 항박테리아, 항균 효능이 있는 것으로 알려져 있다(Abul-Fadl et al., 2011). 또한 Cho et al. (1993a)의 연구에서 갓의 주요 색소 성분인 카로티노이드의 함량 중 $\beta$-carotene이 $80.91 \%$ 이었으며, 클 로로필 $\mathrm{a}, \mathrm{b}$ 의 함량이 각각 $0.41 \mathrm{mg} / \mathrm{g}, 0.15 \mathrm{mg} / \mathrm{g}$ 으로 보고되었다.

따라서 갓의 잎, 종자 추출물의 항산화 활성은 isothiocyanate와 비타민, 카로티노이드 및 클로로필 등의 항산화 성분에 기인한 것으 로 보인다.

\section{3. 갓의 잎, 종자 추출물의 효소 저해활성}

1) Tyrosinase inhibitory activity

Tyrosinase는 멜라닌 생성을 조절하는 효소이다. 이 효소는 tyrosine을 3,4-dihydroxyphenylalanine (DOPA)로 전환하는 tyrosine hydroxylase 활성과 DOPA를 DOPA quinone으로 산화 하는 $\mathrm{DOPA}$ oxidase 활성을 모두 가지고 있어 색소 침착과 관련 이 있는 효소이다. L-tyrosine이 L-DOPA로 산화되는 과정에서 


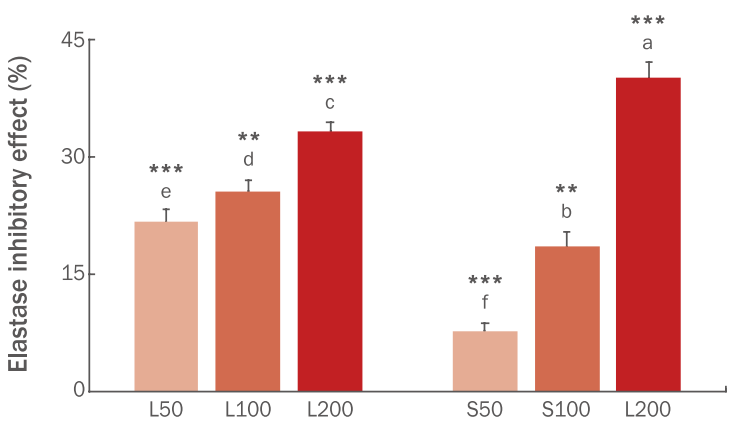

Figure 6. Elastase inhibitory effect of mustard (Brassica juncea L. Czern.) leaf and seed.

The leaf and seed extracts of Brassica juncea L were assessed in concentration of $50,100,200 \mathrm{mg} / \mathrm{mL}$. The result is shown as an average (means $\pm S D, n=3$ ). The significance level was determined to be $p<0.05$ via Duncan's multiple range test. ${ }^{* * *} p<0.001$ shows the significance difference between L50 and S50, L200 and S200 via student's $t$-test. ${ }^{* *} p<0.01$ shows the significance difference between L100 and S100 via student's $t$-test.

melanosome의 melanocyte 내에서 tyrosinase가 촉매역할을 하 여 발생하고, $\mathrm{L}-\mathrm{DOPA}$ 는 산화되어 DOPA quinone으로 전환되며, DOPA quinone이 멜라닌으로 합성되면 eumelanin, pheomelanin 을 만들어내게 된다. Tyrosine에서 L-DOPA, L-DOPA에서 DOPA quinone의 합성 과정에서 tyrosinase 효소 활성을 저해한다면 멜라 닌 합성을 억제할 수 있다(An et al., 2007; Lee et al., 2013).

본 연구에서는 갓의 잎, 종자 추출물 $(50,100,200 \mathrm{mg} / \mathrm{mL})$ 의 미백 효능을 알아보고자 tyrosinase 저해활성을 측정하였으 며 그 결과, 6.54-36.58\% 범위의 값을 보였다(Figure 5). Leaf는 $50 \mathrm{mg} / \mathrm{mL}$ 일 때 $-1.36 \pm 0.53 \%$ 로 활성이 없는 것으로 나타났다. $100 \mathrm{mg} / \mathrm{mL}$ 일 때는 $6.54 \pm 1.89 \%, 200 \mathrm{mg} / \mathrm{mL}$ 일 때는 22.33 $\pm 0.42 \%$ 로 농도가 높을수록 저해활성이 높아졌다. 반면, seed는 $50 \mathrm{mg} / \mathrm{mL}$ 일 때 $36.58 \pm 0.79 \%, 100 \mathrm{mg} / \mathrm{mL}$ 일 때는 $31.89 \pm$ $1.67 \%, 200 \mathrm{mg} / \mathrm{mL}$ 일 때는 $22.52 \pm 1.97 \%$ 로 추출물의 농도가 높 을수록 저해활성이 낮아졌다.

대체로 seed가 leaf 보다 tyrosinase 저해활성이 높았으며, leaf는 농도가 높을수록 tyrosinase 저해활성이 높아져 양의 상관관계를 보 였다. 그러나 seed는 농도가 일정수준 이상이 되면 저해활성이 낮게 나타났다(Figure 5). 이러한 경향은 식물 자체 tyrosinase 효소 활 성이 높거나 기질이 되는 물질의 함량이 높아진 경우로 추정해볼 수 있다(Jung et al., 1995).

Jung et al. (1995)의 연구에 의하면 Brassica 속 식물 중 브로콜 리(Brassica oleracea var. italica)와 꽃양배추(Brassica oleracea var. botrytis)의 tyrosinase 저해활성은 $49 \%$, 청경채(Brassica campestris)는 17\%, 양배추(Brassica olercea capitata)는 12\%, 케일(Brassica olercea var. acephala)은 $6 \%$ 순으로 나타났다. 또
한, Jeong et al. (2018)은 십자화과에 속하는 적콜라비(Brassica oleracea var. gongylodes) 싹의 미백 효능을 알아보기 위해 흑색종 세포(B16F10)를 이용하여 멜라닌 생성 저해활성을 측정한 결과, 추 출물 $2 \%$ 처리 시, $29 \%$ 의 저해활성이 나타나 적콜라비 싹 추출물을 이용한 미백 화장품 개발 가능성이 높은 것으로 보고하였다.

본 연구에서도 십자화과(Brassicaceae)에 속하는 갓(Brassica juncea L. Czern.)의 잎, 종자 추출물(EtOH)의 미백 효능을 알아보 고자 tyrosinase 저해활성을 측정한 결과, 타 십자화과 식물에 비해 높은 활성을 보여 갓의 잎, 종자 추출물은 미백 화장품 소재로써 개 발 가능성이 높을 것으로 생각된다.

\section{2) Elastase inhibitory activity}

Elastin은 피부 진피와 피부 탄력섬유를 구성하는 중요한 성분으 로 elastin의 감소는 피부 주름을 생성하고 탄력을 저하시켜 피부 노화를 촉진시킨다. Elastin을 분해하는 효소로 알려진 elastase는 collagen과 함께 결합조직의 기계적 성질을 결정하는 elastin을 분해 하는데, 동물의 결합조직에서 불용성 탄력섬유 elastin을 분해하는 유일한 효소이며, elastase 저해제는 피부 주름 및 피부 노화를 개선 하는 효과를 기대할 수 있다(Song et al., 2017; Lee et al., 2013).

본 연구에서는 갓의 잎, 종자 추출물 $(50,100,200 \mathrm{mg} / \mathrm{mL})$ 의 elastase 저해활성을 측정하여 항주름 효능을 알아보고자 elastase 저해활성을 측정하였으며 그 결과, $7.81-40.21 \%$ 범위의 값을 보였 다(Figure 6). Leaf와 seed 모두 $200 \mathrm{mg} / \mathrm{mL}$ 농도에서 elastase 저 해활성이 가장 높았으며, $50 \mathrm{mg} / \mathrm{mL}$ 일 때는 leaf $21.80 \pm 1.58 \%$, seed $7.81 \pm 0.98 \%, 100 \mathrm{mg} / \mathrm{mL}$ 일 때는 leaf $25.68 \pm 1.48 \%$, seed $18.61 \pm 1.89 \%, 200 \mathrm{mg} / \mathrm{mL}$ 일 때는 leaf $33.45 \pm 1.14 \%$, seed $40.21 \pm 2.13 \%$ 로 농도가 높아질수록 elastase 저해활성이 높아졌 다.

결과적으로 각각의 추출물 모두 농도가 높을수록 elastase 저해활 성이 높아져 양의 상관관계를 보였고 대체로 leaf가 seed 보다 저해 활성이 높은 것을 알 수 있었다(Figure 6).

Lee et al. (2012)은 브로콜리(Brassica oleracea var. italica Plenck) 새싹 추출물의 collagenase 저해활성을 측정하여 브로콜리 의 collagenase 저해활성이 우수한 것을 보고하였다. 또한 Shin et al. (2016)은 순무(Brassica rapa ssp.) 캘러스 추출물(EtOH)이 프 로 콜라겐 합성을 농도 의존적으로 증가시키는 것을 확인하였으며, 주름 개선에 우수한 효과가 있어 기능성 물질로 활용할 수 있을 것 으로 보고하였다.

본 연구에서도 십자화과(Brassicaceae)에 속하는 갓(Brassica juncea L. Czern.)의 항주름 효능을 알아보고자 elastase 저해활성 을 측정한 결과, 농도 의존적으로 elastase 저해활성이 높아진 것으 로 보아 십자화과에 속하는 타 채소류를 포함하여 갓의 잎, 종자 추 출물은 주름 예방에 우수한 효능이 있어 화장품 소재로써 개발 가능 성이 높을 것으로 생각된다. 


\section{Conclusion}

본 연구는 갓(Brassica juncea L. Czern.)의 잎과 종자 추출물을 화장품 기능성 소재로써 이용하기 위한 생리활성 연구를 통해 그 이 용가치를 규명하고자 하였다. 이에 본 연구에서는 갓의 잎과 종자 추 출물의 생리활성 연구를 위해 항산화 관련 지표로 총 폴리페놀 함량 과 총 플라보노이드 함량, $\mathrm{DPPH}$ radical 소거능과 $\mathrm{ABTS}$ radical 소 거능을 측정하였고, 미백 관련 지표로 tyrosinase 저해활성, 항주름 관련 지표로 elastase 저해활성을 측정하여 분석하였다.

그 결과 갓의 잎, 종자 추출물 $(50,100,200 \mathrm{mg} / \mathrm{mL})$ 의 총 폴 리페놀 함량의 최대치는 각각 $15.03 \mathrm{mg} \mathrm{TAE} / \mathrm{g}, 27.72 \mathrm{mg} \mathrm{TAE} /$ $\mathrm{g}$, 총 플라보노이드 함량은 $58.84 \mathrm{mg} \mathrm{QE} / \mathrm{g}, 126.75 \mathrm{mg} \mathrm{QE} / \mathrm{g}$, $\mathrm{DPPH}$ radical 소거능은 $65.26 \%, 83.17 \%$, ABTS radical 소거능은 $47.06 \%, 60.57 \%$ 로 확인되었다. 항산화 관련 생리활성 평가 결과, 대체로 seed가 leaf 보다 활성이 높았으며, 모두 $200 \mathrm{mg} / \mathrm{mL}$ 농도에 서 가장 높은 결과를 보여 양의 상관관계임을 알 수 있었다.

갓의 잎, 종자 추출물 $(50,100,200 \mathrm{mg} / \mathrm{mL})$ 의 tyrosinase 저해활 성의 최대치는 각각 $22.33 \%, 36.58 \%$, elastase 저해활성은 $33.45 \%$, $40.21 \%$ 였다. Leaf의 경우 농도 의존적으로 tyrosinase 저해활성과 elastase 저해활성이 높아진 반면, seed의 경우 elastase 저해활성에 서는 농도 의존적으로 활성이 높아졌으나 tyrosinase 저해활성에서 는 추출물의 농도가 일정수준 이상이 되면 오히려 활성이 낮아지는 것으로 확인되었다. 이러한 경향은 식물 자체 tyrosinase 효소 활성 이 높거나 기질이 되는 물질 함량이 높아지는 것으로 추정된다.

따라서 본 연구 결과로 갓(Brassica juncea L. Czern.)의 잎과 종 자 추출물 $(\mathrm{EtOH})$ 의 항산화 효능 및 효소활성 억제 효능이 우수한 것 을 규명할 수 있었으며, 향후 화장품 소재로써 그 이용가치가 높을 것으로 판단된다.

\section{Author's contribution}

JEL as the first author, contributed to all aspects of analysis and experimental design, and wrote the manuscript. AJK as the second author, contributed to all the experimental design in detail and correcting the errors directly.

\section{Author details}

Jeong-eun Lee (Graduate student), Department of Alternative Medicine, Kyonggi University, 24, Kyonggidaero-9 gil, Seodaemun-gu, Seoul 03746, Korea; Ae-jung Kim (Professor), Major of Beauty Wellness, The Graduate School of Alternative Medicine, Kyonggi University, 24, Kyonggidaero-9 gil, Seodaemun-gu, Seoul 03752, Korea.

\section{References}

Abul-Fadl MM, El-Badry N, Ammar MS. Nutritional and chemical evaluation for two different varieties of mustard seeds. World Applied Sciences Journal, 15: 1225-1233, 2011.

An IS, Kim JH, Yoo HS, Zhang R, Kang SM, Choe TB, Kwon TJ, An SK, Kim GY. The inhibition effect of L-cysteine on melanogenesis in B16F10 mouse melanoma cells. Asian Journal of Beauty and Cosmetology, 5: 239-246, 2007.

Blois MS. Antioxidant determination by the use of a stable free radical. Nature, 181: 1199-1200, 1958.

Cha JY, Kim HJ, Chung CH, Cho YS. Antioxidative activities and contents of polyphenolic compound of Cudrania tricuspidata. Journal of the Korean Society of Food Science and Nutrition, 28: 1310-1315, 1999.

Cho YS, Ha BS, Park SK, Chun SS. Contents of carotenoids and chlorophylls in Dolsan leaf mustard (Brassica juncea). Journal of the Korean Society of Dietary Culture, 8: 153-157, 1993a.

Cho YS, Park SK, Chun SS, Park JR. Analysis of isothiocyanates in Dolsan leaf mustard (Brassica juncea). Journal of the Korean Society of Food Culture, 8: 147-151, 1993b.

Choi MR, Yoo EJ, Song SH, Kang DS, Park JC, Lim HS. Comparison of physiological activity in different parts of Dolsan leaf mustard. Journal of the Korean Society of Food Science and Nutrition, 30: 721-725, 2001.

Davis WB. Determination of flavanones in Citrus fruits. Analytical Chemistry, 19: 476-478, 1947.

Han YB, Kim MR, Han BH, Han YN. Studies on anti-oxidant component of mustard leaf and seed. Korean Journal of Pharmacognosy, 18: 41-49, 1987.

Heim KE, Tagliaferro AR, Bobilya DJ. Flavonoid antioxidants: chemistry, metabolism and structure-activity relationships. The Journal of Nutritional Biochemistry, 13: 572-584, 2002.

Hertog MGL, Hollman PCH, Van de Putte B. Content of potentially anticarcinogenic flavonoids of tea infusions, wines and fruit juices. Journal of Agricultural and Food Chemistry, 41: 1242-1246, 1993.

Kraunsoe JA, Claridge TD, Lowe G. Inhibition of human leukocyte and porcin pancreatic elastase by homologues of bovine pancreatic trypsin inhibitors. Biochemistry, 35: 
9090-9096, 1996.

Jang HL, Park SY, Lee JH, Hwang MJ, Choi Y, Kim H, Hwang J, Seo D, Kim S, Nam JS. Changes in nutritional composition and physicochemical properties of mustard leaf (Brassica juncea) kimchi during fermentation. The Korean Journal of Food and Nutrition, 29: 706-715, 2016.

Jeong SY, Hwang HL, Ryu EK, Cha JS. Anti-inflammatory, antioxidant and melanin synthesis inhibitory effects of red kohlrabi (Brassica oleracea var. gongylodes) sprouts extract. Korean Society of Cosmetics and Cosmetology, 8: 149-155, 2018.

Jung SW, Lee NK, Kim SJ, Han D. Screening of tyrosinase inhibitor from plants. Korean Journal of Food Science and Technology, 27: 891-896, 1995.

Jung YH, Han JS, Kim AJ. Quality evaluation and antioxidant activity of inner beauty tea prepared from roasted lotus root and burdock. Asian Journal of Beauty and Cosmetology, 17: 235-245, 2019.

Kang SK, Sung NK, Kim YD, Lee JK, Song BH, Kim YW, Park SK. Effects of ethanol extract of leaf mustard(Brassica juncea) on the growth of microorganisms. Journal of the Korean Society of Food Science and Nutrition, 23: 10141019, 1994a.

Kang SK, Sung NK, Kim YD, Shin SC, Seo JS, Choi KS, Park SK. Screening of antimicrobial activity of leaf mustard (Brassica juncea) extract. Journal of the Korean Society of Food Science and Nutrition, 23: 1008-1013, 1994b.

Kang SK. Isolation and antimicrobial activity of antimicrobial substance obtained from leaf mustard (Brassica juncea). Journal of the Korean Society of Food Science and Nutrition, 24: 695-701, 1995.

Kaur C, Kapoor HC. Anti-oxidant activity and total phenolic content of some Asian vegetables. International Journal of Food Science \& Technology, 37: 153-161, 2002.

Kim HJ, Kim SY, Choi YB, Choi SW, Sung ND. Human skin irritation of some natural lachrymatory compounds. Journal of Science Criminal Investigation, 6: 181-189, 2012.

Kim JY, Cho JY, Moon JK, Choi GC, Lee KD, Ham KS, Kim SJ. Change of phenylpropanoic acid and flavonol contents at different growth stage of glasswort (Salicornia herbacea L.). Food Science and Biotechnology, 23: 685-691, 2014.
Lee JH, Kim MG, Lee S, Leem KH. Effects of Bletillae rhizoma on the elastase, collagenase and tyrosinase activities and the procollagen synthesis in Hs68 human fibroblasts. The Korea Journal of Herbology, 28: 9-14, 2013.

Lee JM. Physicochemical characteristics and antioxidant effects of red mustard (Brassica juncea L.) leaf using different drying methods. The Korean Society of Commuity Living Science, 28: 515-524, 2017.

Lee SY, Jun HJ, Yoon JY, Kim TS, Park SI, Lee SP, Park JH, Lee JY. Cosmeceutical activity of broccoli (Brassica oleracea var. italica Plenck) with different light sources. Journal of Life Science, 22: 347-357, 2012.

Lim HS. The studies of physiological activity and development as functional foods from Dolsan leaf mustard. Ministry of Agriculture and Forestry, Gwacheon-si, pp93-96, 2002.

Oh SK, Kim KW, Bae SO, Choi MR. Sinigrin content of different parts of Dolsan leaf mustard. Korean Journal of Food Preservation, 22: 553-558, 2015.

Oh SK, Kim KW, Choi MR. Antioxidant activity of different parts of Dolsan leaf mustard. Food Science and Biotechnology, 25: 1463-1467, 2016.

Park BY, Ryu MJ. Assessment on the biological activities of mint, cinnamon and mixed extract and stability of the shampoo. Asian Journal of Beauty and Cosmetology, 19: 247-256, 2019.

Park SK, Cho YS, Park JR, Chun SS, Moon JS. Non-volatile organic acids, mineral, fatty acids and fiber compositions in Dolsan leaf mustard (Brassica juncea). Journal of the Korean Society of Food Science and Nutrition, 22: 5357, 1993.

Park SK, Park JR, Lee SW, Seo KI, Kang SK, Shim KH. Antimicrobial activity and heat stability of waterpretreated extract of leaf mustard Dolsan (Brassica juncea). Journal of the Korean Society of Food Science and Nutrition, 24: 707-712, 1995.

Pellegrin N, Roberta R, Min Y, Catherine RE. Screening of dietary carotenoids and carotenoid-rich fruit extracts for antioxidant activities applying 2,2'-azinobis(3thylenebenzothiazoline-6-sulfonic acid) radical cation decolorization assay. Method in Enzymology, 1999: 379389, 1999.

Seo KI, Park SK, Park JR, Kim HC, Choi JS, Shim KH. Changes in antimicrobial activity of hydrolyzate from mustard seed 
(Brassica juncea). Journal of the Korean Society of Food Science and Nutrition, 25: 129-134, 1996.

Shin GH, Lee YJ, Kim JH, Kim YH, Kim DB, Lee JS, Lim JH, Lee $\mathrm{OH}$. Antioxidant activities of commonly used Brassica spp. sprout vegetables in Korea. Korean Journal of Food Preservation, 21: 587-592, 2014.

Shin SW, Kang CA. Studies on compositions and antifungal activities of essential oils from cultivars of Brassica juncea L. Korean Journal of Pharmacognosy, 32: 140144, 2001.

Shin SW. Analysis of essential oils from several cultivars of Brassica juncea L. Duksung Bulletin of Pharmaceutical Sciences, 11: 17-22, 2000.

Shin SY, Moh SH, Hwang YJ. Biological activities of Brassica rapa (Turnip) callus extracts by plant cell culture technology. Journal of Plant Biotechnology, 43: 248-254, 2016.

Singleton VL, Rossi JA. Colorimetry of total phenolics with phosphomolybdic-phosphotungstic acid reagents. American Journal of Enology and Viticulture, 16: 144-
158, 1965.

Song BJ, Cho JY, Ma SJ, Park KJ, Park HJ, Choi GC, Ha H, $\mathrm{Na}$ HS. Antioxidant, anti-tyrosinase and anti-elastase activities of alternative tea materials (mugwort, bower actinidia, arrowroot) by harvest time and region: $\mathrm{A}$ comparative in vitro study. Journal of the Korean Tea Society, 23: 65-73, 2017.

Tomita K, Oda N, Ohbayashi M, Kamei H, Miyaki T, Oki T. A new screening method for melanin biosynthesis inhibitors using Streptomyces bikiniensis. The Journal of Antibiotic, 43: 1601-1605, 1990.

Kumar V, Thakur DA, Barothia ND, Chatterjee SS. Therapeutic potentials of Brassica juncea: an overview. TANG humanitas medicine, 1: 1-17, 2011.

Yahaghi Z, Shirvani M, Nourbakhsh F, de la Pena TC, Pueyo JJ, Talebi M. Isolation and characterization of Pb-solubilizing bacteria and their effects on $\mathrm{Pb}$ uptake by Brassica juncea: Implications for microbeassisted phytoremediation. Journal of microbiology and biotechnology, 28: 1156-1167, 2018. 


\section{국문초록}

\section{갓(Brassica juncea L. Czern.)의 잎과 종자 추출물의 항산화, 미백 및 항주름 효능}

이정은 ${ }^{1}$, 김애정 ${ }^{2 *}$

${ }^{1}$ 경기대학교 대체의학과, 서울, 한국

${ }^{2}$ 경기대학교 대체의학대학원 뷰티웰니스전공, 서울, 한국

목적: 본 연구는 갓의 잎과 종자 추출물의 생리활성 평가를 실시하여 화장품 소재로써 이용가치를 규명하고자 하였다. 방법: 생리 활성 평가를 위해 갓의 잎, 종자 추출물 $(\mathrm{EtOH})$ 의 총 폴리페놀, 총 플라보노이드 함량, $\mathrm{DPPH}$ radical 소거능, $\mathrm{ABTS}$ radical 소거능, tyrosinase 저해활성, elastase 저해활성을 측정하였다. 또한 농도에 따른 항산화 효능 및 효소 저해활성을 알아보기 위해 각 추출물 의 농도 $(50,100,200 \mathrm{mg} / \mathrm{mL})$ 를 다르게 하여 상관관계를 비교분석 하였다. 결과: 갓의 잎, 종자 추출물 $(50,100,200 \mathrm{mg} / \mathrm{mL})$ 의 총 폴리페놀 함량의 최대치는 각각 $15.03 \mathrm{mg} \mathrm{TAE} / \mathrm{g}, 27.72 \mathrm{mg} \mathrm{TAE} / \mathrm{g}$, 총 플라보노이드 함량은 $58.84 \mathrm{mg} \mathrm{QE} / \mathrm{g}, 126.75 \mathrm{mg} \mathrm{QE} /$ $\mathrm{g}$, DPPH radical 소거능은 $65.26 \%, 83.17 \%, \mathrm{ABTS}$ radical 소거능은 $47.06 \%, 60.57 \%$ 로 확인되었다. 항산화 관련 생리활성 평가 결 과, 대체로 seed가 leaf 보다 활성이 높았으며, 모두 $200 \mathrm{mg} / \mathrm{mL}$ 농도에서 가장 높은 결과를 보여 양의 상관관계임을 알 수 있었다. Tyrosinase 저해활성의 최대치는 각각 $22.33 \%, 36.58 \%$, elastase 저해활성은 $33.45 \%, 40.21 \%$ 였다. Leaf의 경우 농도 의존적으로 tyrosinase 저해활성과 elastase 저해활성이 높아진 반면, seed의 경우 elastase 저해활성에서는 농도 의존적으로 활성이 높아졌으나 tyrosinase 저해활성에서는 추출물의 농도가 일정수준 이상이 되면 오히려 활성이 낮아지는 것으로 확인되었다. 결론: 본 연구 결과 로 갓(Brassica juncea L. Czern.)의 잎과 종자 추출물은 항산화 효능, tyrosinase 및 elastase 활성 억제 효능의 우수성을 규명할 수 있었으며, 향후 화장품 소재로써 그 이용가치가 높을 것으로 판단된다.

핵심어: 갓, 항산화, Tyrosinase 저해활성, Elastase 저해활성, 생리활성

\section{참고문헌}

강성구, 성낙계, 김용두, 신수철, 서재신, 최갑성, 박석규. 갓(Brassica juncea)추출물의 항균활성 검색. 한국식품영양과학 회지, 23: 1008-1013, 1994b.

강성구, 성낙계, 김용두, 이재근, 송보현, 김영환, 박석규. 갓(Brassica jucnea)의 에탄올추출물이 미생물 생육에 미치는 영향. 한국식품영양과학회지, 23: 1014-1019, 1994a.

강성구. 갓(Brassica juncea)의 항균물질의 분리 및 항균성. 한국식품영양과학회지, 24: 695-701, 1995.

김해중, 김수연, 최용복, 최성운, 성낙도. 몇 가지 천연 최루성 화합물의 인체피부 감작성. 과학수사학회지, $6: 181-189$, 2012 .

박보연, 유민정. 박하와 계피 그리고 혼합 추출물의 생리활성 및 샴푸의 안정성 평가. 아시안뷰티화장품학술지, 19: 247256, 2019.

박석규, 박정로, 이상원, 서권일, 강성구, 심기환. 돌산 갓 전처리 추출물의 항균활성 및 열안정성. 한국식품영양과학회지, 24: 707-712, 1995.

박석규, 조영숙, 박정로, 전순실, 문주석. 돌산 갓의 비휘발성 유기산, 무기질, 지방산 및 섬유소 조성. 한국식품영양과학 회지, 22: 53-57, 1993.

서권일, 박석규, 박정로, 김홍출, 최진상, 심기환. 겨자 가수분해물의 항균성 변화. 한국식품영양과학회지, 25: $129-134$, 1996.

송병준, 조정용, 마승진, 박경진, 박학재, 최경철, 하훈, 나환식. 쑥, 칡잎 그리고 다래잎의 채취시기 및 지역별 항산화, tyrosinase 저해 및 elastase 저해 활성. 한국차학회지, 23: 65-73, 2017. 
신기해, 이영준, 김재환, 김영현, 김단비, 이종석, 임정호, 이옥환. 국내 다소비 십자화과 새싹채소 추출물의 항산화 활성. 한국식품저장유통학회지, 21: 587-592, 2014.

신수영, 모상현, 황유진. 식물세포배양기술을 이용한 순무 캘러스 추출물의 생리활성. 식물생명공학회지, 43: 248-254, 2016.

신승원, 강찬아. 갓 정유의 조성 및 항진균작용에 관한 연구. 생약학회지, $32: 140-144,2001$.

신승원. Brassica juncea L. 의 재배품종 정유의 비교분석. 덕성여자대학교 약학논문지, 11: 17-22, 2000

안인숙, 김지혜, 유회숙, 장뢰, 강상모, 최태부, 권태종, 안성관, 김기연. B16F10 Mouse Melanoma 세포에서의

L-cystein에 의한 멜라닌 생성 억제. 아시안뷰티화장품학술지, 5: 239-246, 2007.

오선경, 김기웅, 배상옥, 최명락. 돌산갓의 부위별 sinigrin 함량. 한국식품저장유통학회지, $22: 553-558,2015$.

이수연, 전혜지, 윤지영, 김태수, 박소이, 이성표, 박주훈, 이진영. 광원별 브로콜리 추출물의 화장품 약리활성 검증. 생명 과학회지, 22: 347-353, 2012.

이주민. 건조방법에 따른 적겨자잎의 이화학적 성분 및 항산화효과 비교. 한국지역사회생활과학회지, $28: 515-524$, 2017.

이인호, 박종인, 정건호, 노일섭. 갓 품종간의 형질 및 광합성 변이. 생명과학회지, 20: 1127-1133, 2010.

임현수. 돌산 갓의 생리기능성 탐색 및 응용식품개발. 농림부, 과천, pp93-96, 2002.

장혜림, 박서연, 이종헌, 황명진, 최용민, 김행란, 황진봉, 서동원, 김상희, 남진식. 갓김치(Brassica juncea) 숙성 중 영양 성분 및 이화학적 특성 변화. 한국식품영양학회지, 29: 706-715, 2016.

정선영, 황혜리, 유은경, 차준석. 적콜라비싹추출물의 항산화, 항염 및 미백 효과. 한국화장품미용학회지, 8: 149-155, 2018.

정승원, 이남경, 김석중, 한대석. Tyrosinase활성을 저해하는 식물체의 탐색. 한국식품과학회지, 27: 891-896, 1995.

정연희, 한정순, 김애정. 로스팅한 연근과 우엉을 이용한 이너 뷰티 차의 항산화 활성과 품질 평가. 아시안뷰티화장품학술 지, 17: 235-245, 2019.

조영숙, 박석규, 전순실, 박정로. 돌산 갓의 Isothiocyanate류의 분석. 한국식생활문화학회지, 8: 147-151, 1993b

조영숙, 하봉석, 박석규, 전순실. 돌산 갓의 Carotenoids 및 Chlorophyll 함량. 한국식생활문화학회지, 8: 153-157, 1993a.

차재영, 김현정, 정정한, 조영수. 꾸지뽕나무(Cudrania tricuspidata)의 폴리페놀 화합물 함량과 항산화 활성. 한국식품영 양과학회지, 28: 1310-1315, 1999.

최명락, 유은정, 송상호, 강동수, 박종철, 임현수. 돌산 갓의 부위별 생리활성 작용의 비교. 한국식품영양과학회지, 30 : $721-725,2001$.

한용봉, 김미라, 한병훈, 한용남. 갓과 겨자의 항산화 활성성분에 관한 연구. 생약학회지, 18: 41-49, 1987. 


\section{中文摘要}

\section{芥荣(Brassica juncea L. Czern.)叶和种子提取物的抗氧化、美白和抗皱功能}

李姃恩 ${ }^{1}$, 金愛貞 $^{2 *}$

1京畿大学代替医疗学科, 首尔, 韩国

2京畿大学代替医疗大学院美容保健专业, 首尔, 韩国

目的：评估芥荣叶和种子提取物的生物活性，并检验其作为化妆品成分的实用价值。方法：测定总多酚，总黄酮 含量, DPPH自由基清除活性, ABTS自由基清除活性以及酪氨酸酶和弹性蛋白酶的抑制活性, 以评价芥荣叶和 种子提取物的生物活性。另外, 为了研究抗氧化剂作用和酶抑制活性与浓度的关系, 比较分析了每种提取物的 50、 100 和 $200 \mathrm{mg} / \mathrm{mL}$ 不同浓度的相关性。结果: 芥荣叶和种子提取物中总多酚含量最高（分别为 $50 、 100$ 和 $200 \mathrm{mg} / \mathrm{mL}$ ) , 分别为 15.03 和 $27.72 \mathrm{mg} \mathrm{TAE} / \mathrm{g}$, 而总黄酮含量分别为58.84和 $126.75 \mathrm{mg} \mathrm{QE} / \mathrm{g}$ 。在叶提取物 中证实了DPPH清除作用为 $65.26 \%$, 在种子提取物中证实为 $83.17 \%$, 而在叶提取物中证实了ABTS自由基清除 作用为 $47.06 \%$ ，在种子萃取物中为 $60.57 \%$ 。生物活性分析对抗氧化作用的评价结果是，种子中的活性高于叶 中的活性, 并且表明正相关性, 因为对于叶和种子, 在 $200 \mathrm{mg} / \mathrm{mL}$ 的浓度下, 显示出最高的活性。酪氨酸酶的 最高抑制活性分别为 $22.33 \%$ 和 $36.58 \%$ ，而弹性蛋白酶的抑制活性分别为 $33.45 \%$ 和 $40.21 \%$ 。在叶提取物中, 酪氨酸酶和弹性蛋白酶的抑制活性随浓度的增加而增加, 而在种子提取物中, 弹性蛋白酶的抑制活性随浓度的 增加而增加, 但当提取物的浓度达到一定水平以上时, 其抑制活性降低。结论: 研究结果证实了芸苔属芥子的叶 和种子提取物。对酪氨酸酶和弹性蛋白酶的活性具有极好的抗氧化作用和抑制作用，它们作为化妆品成分的实 用价值很高。

关键词: 芥荣型油荣，抗氧化活性，酪氨酸酶抑制活性，弹性蛋白酶抑制活性，生物活性 
